\title{
A CASE OF FAHR'S SYNDROME
}

Ishan Pranay ${ }^{1}$, Ashutosh Chitnis², Vyankatesh Aironi³ ${ }^{3}$ Pankaj Yadav ${ }^{4}$, Rakesh Patil ${ }^{5}$

\section{HOW TO CITE THIS ARTICLE:}

Ishan Pranay, Ashutosh Chitnis, Vyankatesh Aironi, Pankaj Yadav, Rakesh Patil. "A Case of Fahr's Syndrome". Journal of Evolution of Medical and Dental Sciences 2015; Vol. 4, Issue 63, August 06; Page: 11099-11101, DOI: $10.14260 /$ jemds/2015/1600

ABSTRACT: Fahr's disease, also known as familial cerebral ferrocalcinosis disorder characterized by abnormal calcium deposition the disease was first noted by German neurologist. Karl Theodre Fahr.[1] in 1930 It is a rare genetically.[2] dominant neurological disorder with less than 20 families had been reported. We present a case of a 50 year old Male a resident of Akurli, New panvel, Raigad with history of trauma 12 years back and history of loss of consciousness on two occasions with an interval of four years each to trauma, no other significant history of metabolic disease, infection or toxic diseases.

\section{KEYWORDS: FAHR'S SYNDROME}

INTRODUCTION: Fahr's disease or syndrome is characterized by deposition of calcium in bilateral basal ganglia especially in lenticular nucleus and internal globus pallidus.[3] also in caudate nucleus, putamen, thalamus and brainstem it has been associated with genetic heterogeneity on chromosome 8 which contains gene encoding the type III sodium dependent phosphate transporter 2 [SLC20A2.[4] Histologically concentric calcium deposits within the walls of small and medium-sized arteries are present.

\section{The C T finding of the patient were:}

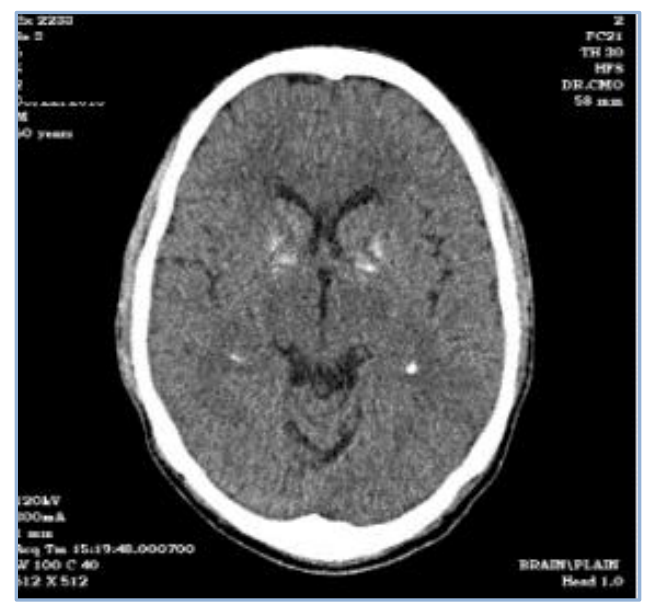

Fig. 1: Axial non-contrast CT image shows calcification in bilateral Putamen and Globus Pallidus

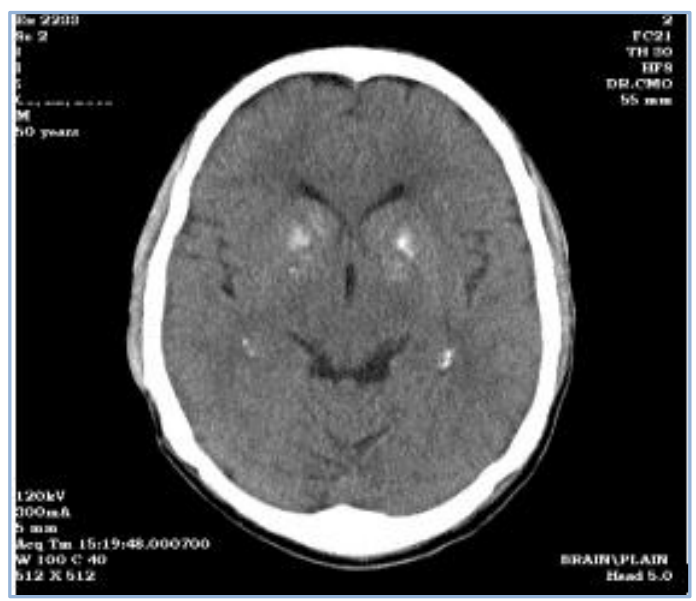

Fig 2: Axial Images Shows Calcification in basal Ganglia 


\section{CASE REPORT}

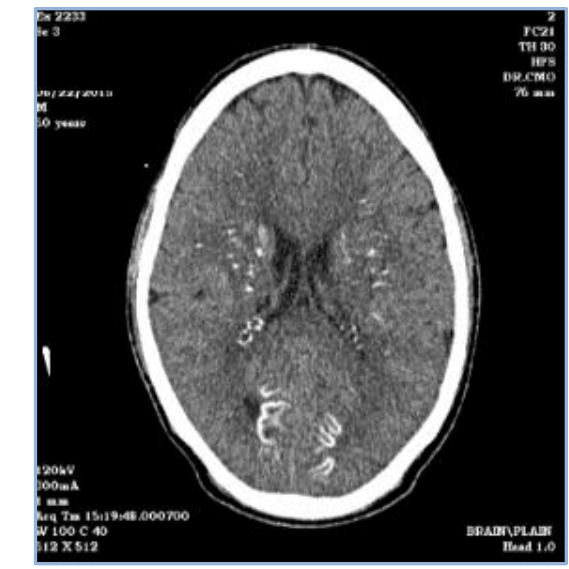

Fig 3: Ct image shows dense calcifications in para-ventricular region and occipital lobe

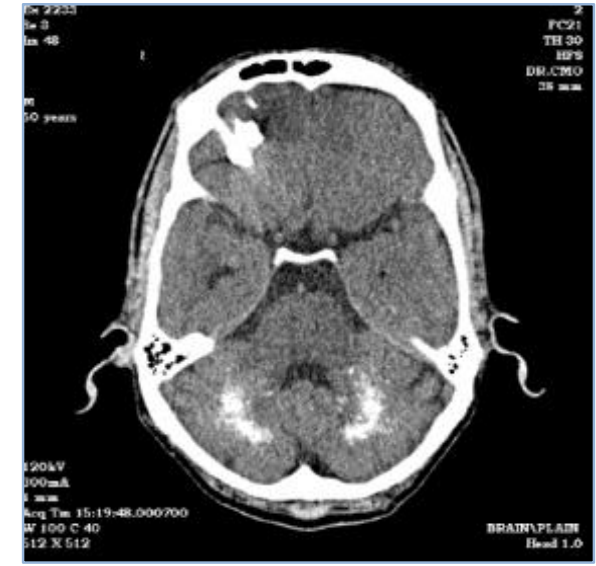

Fig 4: Axial Ct image Shows classification in Dentate nucleus

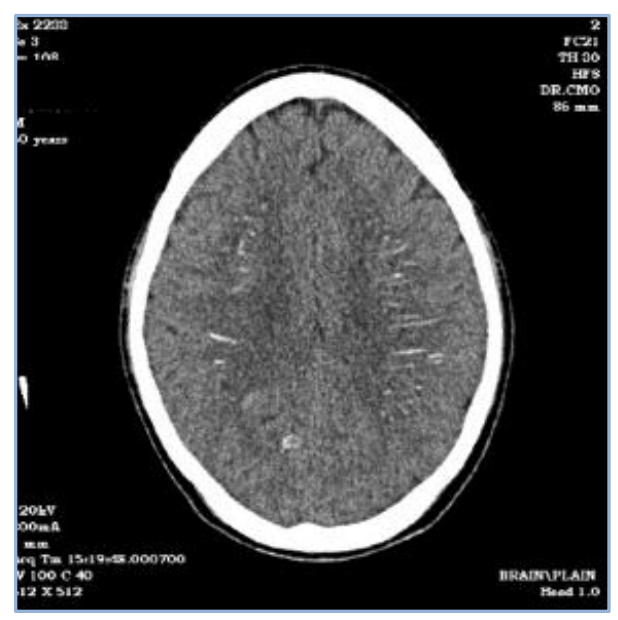

Fig 5: Non-contrast Ct shows classification in corona Radiata

1The Patient was further subjected for biochemical analysis which showed the following findings:

Serum Calcium measures: $6.6 \mathrm{mg} / \mathrm{dl}$ (normal range $8-10 \mathrm{mg} / \mathrm{dl}$ ).

Serum Parathyroid level measures: $1.8 \mathrm{pg} / \mathrm{ml}(15-65 \mathrm{pg} / \mathrm{ml})$.

DISCUSSION: Fahr's disease presents from childhood is seen with motor deficits and 40\% present with cognitive and other psychiatric abnormalities. Our patient however presented with no such symptoms other than seizures but presented with dense basal calcification secondary to hypoparathyroidism and no other etiology such as CMV, Neurocysticercosis pseudohypoparathyroidism, Hypervitaminosis D, Pseudohypoparathyroidism. ${ }^{[5]}$ This patient is a rare cause of fahr's syndrome presenting with seizures.[6] 


\section{REFERENCES:}

1. Fahr, T. (1930-1931). "Idiopathische Verkalkung der Hirngefässe".Zentralblatt für allgemeine Pathologie und pathologische Anatomie 50: 129-133.

2. Rarediseases.info.nih.gov/GARD/Disease.aspxPageID=4\&diseaseID=8272.

3. Bonazza S, La Morgia C, Martinelli P, Capellari S (August 2011). "Strio-pallido-dentate calcinosis: a diagnostic approach in adult patients". Neuro. Sci. 32 (4): 537-45. Doi: 10.1007/s10072-011-0514-7. PMID 21479613.

4. Wang C, Li Y, Shi L et al. (March 2012). "Mutations in SLC20A2 link familial idiopathic basal ganglia calcification with phosphate homeostasis". Nat. Genet. 44(3):254-6. Doi: 10.1038/ng.1077.PMID 22327515.

5. Olivera JR, Spiteri E, Sobrido MJ, et al. genetic Heterogenisity in Familial Idiopathic Basal Calcification (Fahr's disease) Neurology 2004; 63:2165-7.

6. Sinha R,Sodhi K, John BM, Singh D. Fahr's Disease: A Case Report. J Nepal Paediatr Soc 2010; 30 (1):44-45.

\section{AUTHORS:}

1. Ishan Pranay

2. Ashutosh Chitnis

3. Vyankatesh Aironi

4. Pankaj Yadav

5. Rakesh Patil

\section{PARTICULARS OF CONTRIBUTORS:}

1. Second Year Junior Resident, Department of Radiodiagnosis, M.G.M. Medical College and Hospital, Kamothe, Navi Mumbai.

2. Associate Professor, Department of Radiodiagnosis, M.G.M. Medical College and Hospital, Kamothe, Navi Mumbai.

3. Associate Professor, Department of Radiodiagnosis, M.G.M. Medical College and Hospital, Kamothe, Navi Mumbai.
FINANCIAL OR OTHER COMPETING INTERESTS: None
4. Second Year Junior Resident, Department of Radiodiagnosis, M.G.M. Medical College and Hospital, Kamothe, Navi Mumbai.

5. Second Year Junior Resident, Department of Radiodiagnosis, M.G.M. Medical College and Hospital, Kamothe, Navi Mumbai.

\section{NAME ADDRESS EMAIL ID OF THE CORRESPONDING AUTHOR:}

Dr. Ishan Pranay Room No-507, P.G. Hostel,

M. G. M. Medical College,

Kamothe, Navi Mumbai.

E-mail: ishan.pranay07@gmail.com

Date of Submission: 04/07/2015.

Date of Peer Review: 06/07/2015.

Date of Acceptance: 25/07/2015.

Date of Publishing: 06/08/2015. 